\title{
研究報文
}

\section{カバークロップの種類と残渣処理が不耕起播種機利用時の トラクタの所要動力に及ぼす影響}

\author{
趙 艶忠*・趙 鉄軍** ·小松㠃将一*** \\ *中国東北農業大学工程学院 \\ ** 東京農工大学連合農学研究科 \\ *** 茨城大学農学部
}

\begin{abstract}
Tractor Power Requirement of No-Tillage Seeder under
\end{abstract}
Different Cover Crop Residue Management

\author{
Yanzhong ZhaO*, Tiejun Zhaо* and Masakazu KomatsuZAKI*** \\ * College of Agricultural Engineering, Northeast Agricultural University, China \\ ** Tokyo University of Agriculture and Technology \\ *** College of Agriculture, Ibaraki University
}

\section{1. 緒言}

緑肥やカバークロップの利用は『持続性の高い 農業生産方式の促進に関する法律（持続農業法)』 にもとづく各都道府県における環境保全的な農業 技術の導入政策の中で，「土づくり」および「化学 肥料の削減」対策技術として位置づけられてい る. 環境保全型農業技術の土づくりが堆肥の施用 に集中されている中で，カバークロップの利用は 作付体系㧍よび農作業体系全体からの改善であ り, 地域環境の保全之農業生産性の維持向上との 調和という視点からは, 堆肥施用では得られない 様々な特徴を有しているあのと考えられる。 とく に, 冬作のカバークロップの作付は土壌浸食や雑 草の抑制, 養分供給, 環境負荷を軽減するなど効 果があり, 地域環境の持続性の向上に貢献する技 術として注目されている（Touchton et al. 1982, Edelhar et al. 1984, Wagger et al. 1989, Oyer et al. 1990, Araki et al. 1998).

平成 21 年 9 月 25 日受付

平成 22 年 2 月 13 日受理

Corresponding author

小松㠃将一 Masakazu Komatsuzaki

干300-0393 茨城県稲敷郡阿見町中央 3-21-1

3-21-1 Chuou, Ami, Inashiki, Ibaraki, 300-0393, Japan

E-mail : komachan@mx.ibaraki.ac.jp
カバークロップを利用した農作業システムに関 する研究では, カバークロップ作後の夏作物栽培の ための耕うん法について，不耕起で播種する場合 (Triplett et al. 1996, Myers et al. 1991, Ranells et al. 1992, Wagger 1989), 緑肥としてプラウです き込む場合（西崎 1995, Wood et al. 1991)，およ びロータリ耕による場合などがある（安江 1993， 後藤 1995，幸ら 2002）。プラウ耕やロータリ耕に よるすき込み方法については技術的にほぼ完成し ているのに対し, 不耕起播種技術については研究 段階のものが多い.

不耕起栽培は雑草抑制 (Teasdale 1993), 施肥 量削減 (Sainju et al. 1997, Abdul-Baki et al. 1997), 保水性維持 (McVay et al. 1989) などの効果が期 待できることが欧米を中心とした研究で明らかに なってきた。 日本では不耕起播種機を用いること で, 播種前の耕起・砕土及び中耕培土作業が省略 でき, 作業能率を $1.7 \sim 2.7 \mathrm{~h} \cdot \mathrm{ha}^{-1}$ 之省力的に作 業できることが報告されている（岩手県農業研究 センター2003). 不耕起栽培は米国などで広く普及 しているが，日本と中国などアジアではまだ普及 には至っていない，中国での不耕起播種機の作業 性に関する研究をみると, 作物残渣量が播種精度, 播種深度, 発芽率など不耕起播種機の作業性に 及ぼす影響が研究されているが (Liu et al. 2008, 
Gong et al. 2008)， カバークロップ利用条件下で の検討事例は少ない。一方, 日本では不耕起播種 機技術については麦作後の作業性に関する研究が なされ（金谷ら 2005），また，カバークロップ残渣 で被覆した圃場での機械播種した場合の作物の成 長についての報告（荒木ら 2006）などがあるのみ であり，多様なカバークロップ利用条件下で，現 在普及している汎用型の不耕起播種機の作業性に 関しての検討事例は少ない。とくに，現行の不耕 起播種体系では，耕うんを前提としたトラク夕が 利用されているため不耕起播種動力に必要となる 動力以上の駆動力を保持するトラクタが用いら れ, 不耕起栽培継続に伴う土壤硬度の上昇をむた らし, 不耕起栽培での生産性阻害の大きな要因之 なっている（Ferreras et al. 2000)。 そのため，よ り少ない駆動力のトラクタを中心して作業可能 な栽培システムの構築は不耕起播種技術を低コス 卜，省エネルギで実現するために必須である。

本研究では, カバークロップの種類と残渣処理 方法が汎用型の不耕起播種機利用時のトラクタの 所要動力に及ぼす影響を検討し，カバークロップ 利用之組み合わせた不耕起播種機の効率的な利用 体系について考察する.

\section{2. 材料および方法}

1）供試圃場およびカバークロップ処理方法

供試圃場は茨城大学農学部附属フィールドサイ エンス教育研究センターである (土性 : CL, LiC). 平成 20 年 10 月 17 日にロータリで耕うんし, カバー クロップとしては, ヘアリーベッチ (Vicia villosa Roth.), ライムギ (Secale cereale L.), ヘアリー ベッチとライムギの種子を混播する区（以下，混 播区を称する）を設定した。供試圃場の面積は 1 処理区あたり $4 \mathrm{~m} \times 20 \mathrm{~m}$ とした。播種量はへア リーベッチ区で $52 \mathrm{~kg} / \mathrm{ha}$, ライムギ区で $104 \mathrm{~kg} /$ ha, 混播区でへアリーベッチ $52 \mathrm{~kg} / \mathrm{ha}$ ，ライムギ $52 \mathrm{~kg} / \mathrm{ha}$ とした.

カバークロップの残渣処理は残渣を除去する区 (残渣除去区), フレールモアでカバークロップ残 渣を約 $5 \mathrm{~cm}$ に細断した区 (フレールモア区), 草 刈機で刈り倒し区(刈り倒し区) を設けた. カバー クロップの細断作業にはフレールモア（松山,

FNC1601）を用い, 刈り倒しには肩掛式の草刈機 を用いた。

汎用型不耕起播種機 (三菱農機製 MJSE18-6, 6 条, 作業幅 $1.8 \mathrm{~m}$ ) の作業時は, トラク夕は MF 133 (エンジン出力 $28 \mathrm{~kW}, 2360 \mathrm{cc}$, エンジン回転数 $1000 \mathrm{rpm}, \mathrm{PTO} 1$ 速) を用いて, ダイズ種子 (品種 : エンレイ）を播種した（写真 1$)$.
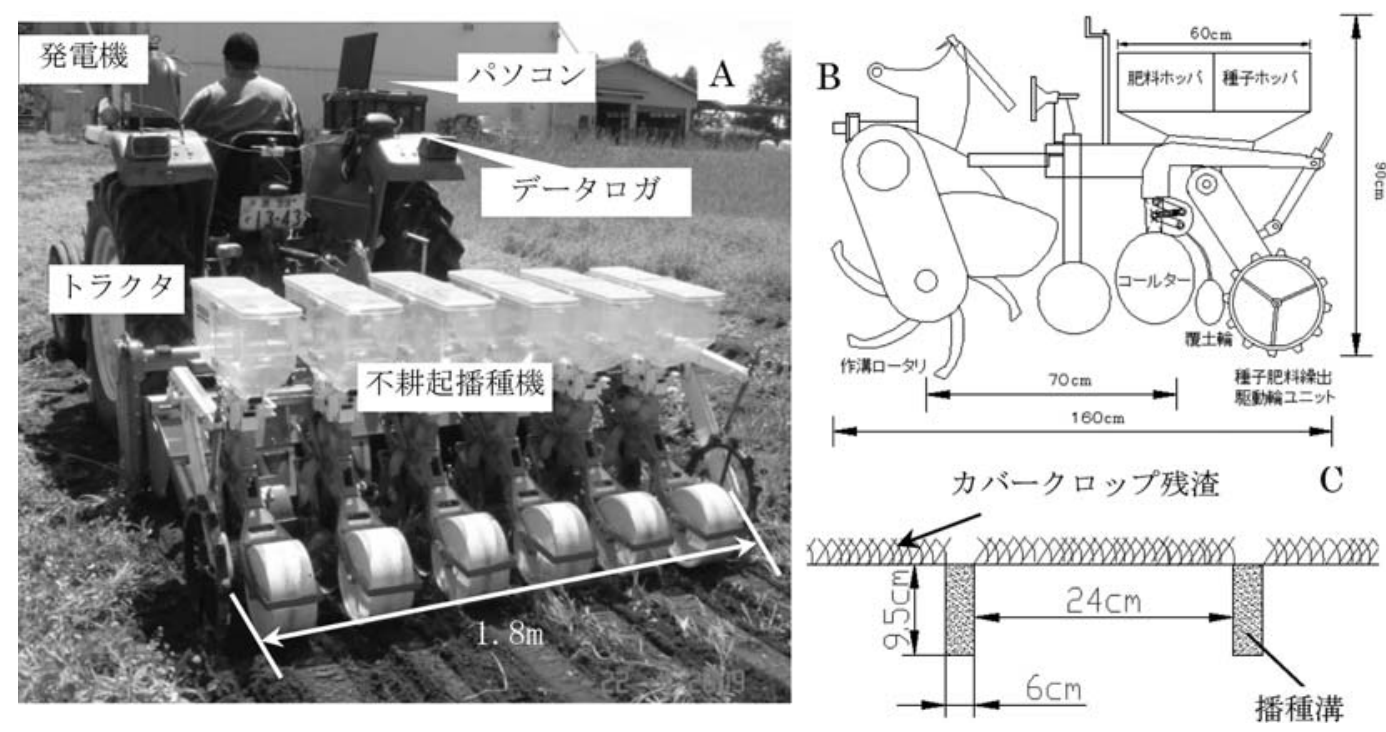

写真 1 試験風景と供試した不耕起播種機の構造

注 : A は測定作業全景, B は汎用型不耕起播種機の寸法, および C は固場断面図を示す. 
2）不耕起播種機の所要動力の測定

試験は 2009 年 4 月 22 日と 5 月 10 日に実施し た. 計測システムは電磁式トルクメータ（日計電 測株式会社, TQR-600NF65M3), A/D 变換器, お よびノートパソコンなどから構成した (写真 2). トルクメータの定格容量は $600 \mathrm{~N} \cdot \mathrm{m}$ であり, ト ラクタの PTO 軸に取り付けたトルクメータと回 転計 (小野測器, TM-2130) より得られたデータ は, アナログ計測変換器（アズワン製，AK-V1） を介してUSBで接続したノートパソコンにリア ルタイムで記録した. PTO 軸の所要動力（以下， 所要動力と称す) $P(\mathrm{~kW})$ は, PTO 軸トルク $T$ $(\mathrm{N} \cdot \mathrm{m})$ （作業期間, 全部採様点の平均值), PTO 軸回転数 $n(\mathrm{rpm})$ より次式を用いて算出した.

$$
P=\frac{T n}{9550}
$$

3）作業および圃場条件の測定

試験前には圃場条件を把握するために 0 ～ $5 \mathrm{~cm}$ まで土畩乾燥密度 (乾熱法), $0 \sim 12 \mathrm{~cm}$ の土壌水 分および 0 ～ $12.5 \mathrm{~cm}$ の深さ $2.5 \mathrm{~cm}$ ごとの土壌硬 度 (SC900 Soil Compaction Meter, Spectrum

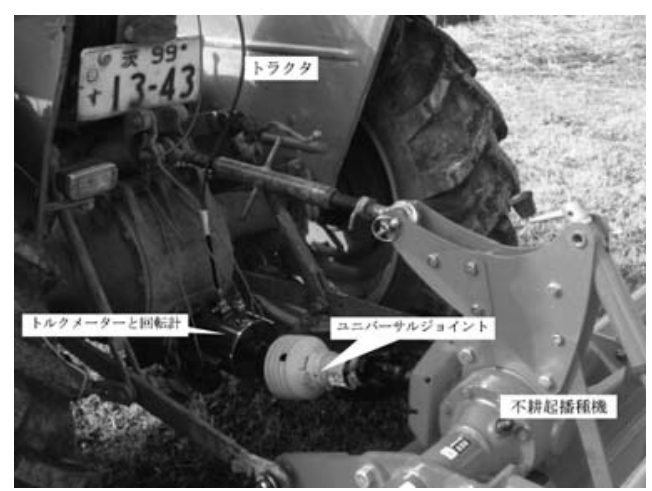

写真 2 トラクタの PTO 軸へのトルクメータ の取付位置図
Technologies, Inc.) (3 反復)を測定した. さらに, $0.25 \mathrm{~m}^{2}$ のコドラートを用い, それぞれのカバーク ロップの乾物重を測定した。 また，播種作業後に 不耕起播種機による播種溝深さおよびダイズ種子 の播種深さ（3反復）を測定した.

\section{3. 結果および考察}

1）圃場および作業条件

カバークロップの種類別の圃場条件をみると， 土壤水分はカバークロップ区で裸地より高かった が，土壌乾燥密度は裸地およびカバークロップの 種類間では同等の值を示した. また，カバークロッ プの乾物重は，4月 22 日に比べると，5月 10 日で はライムギ区で $60 \%$ 増加し，混播区では $31.2 \%$ 増加した（図 1).これに対しへアリーベッチで は，両者に差異は少なかった。

土壌硬度は, 表層ではカバークロップの種類間 での差異は認められなかったが， $6 \mathrm{~cm}$ 以下の土 層では裸地区に比べてカバークロップ区で土壌硬 度が増加した（図 2).

一般に不耕起条件下では裸地に比べてカバーク ロップ利用により土壌硬度が減少することが指摘

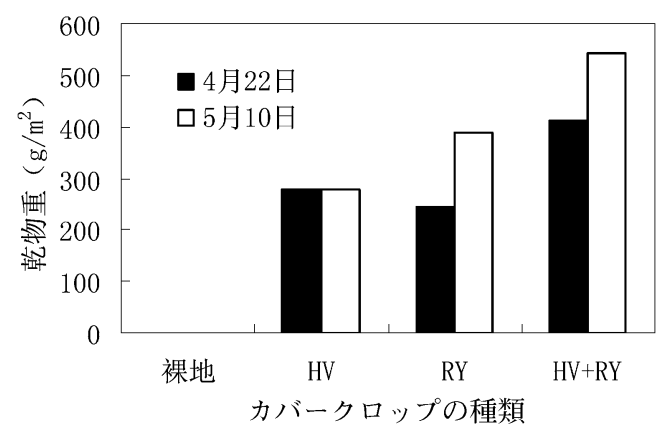

図 1 カバークロップ残渣量の乾物重

注 : 横軸の記号は HV:ヘアリーベッチ, RY : ライ ムギ, $\mathrm{HV}+\mathrm{RY}:$ ヘアリーベッチ+ライムギの 混播を示す.

表 1 圃場試験時の土壌条件

\begin{tabular}{|c|c|c|c|c|c|}
\hline 調査日 & 項目 & 裸地 & ヘアリーベッチ & ライムギ & $\begin{array}{c}\text { ヘアリーベッチ } \\
+ \text { +ライムギ }\end{array}$ \\
\hline 4 月 22 日 & $\begin{array}{c}\text { 土壌水分 }(\%) \\
\text { 土壤乾燥密度 }\left(\mathrm{g} / \mathrm{cm}^{3}\right)\end{array}$ & $\begin{array}{r}10 \pm 0.68 \\
0.59 \pm 0.02\end{array}$ & $\begin{array}{c}26 \pm 7.2 \\
0.61 \pm 0.02\end{array}$ & $\begin{array}{r}14 \pm 1.26 \\
0.63 \pm 0.02\end{array}$ & $\begin{array}{c}15 \pm 4.2 \\
0.67 \pm 0.04\end{array}$ \\
\hline 5 月 10 日 & $\begin{array}{c}\text { 土畩水分 }(\%) \\
\text { 土壤乾燥密度 }\left(\mathrm{g} / \mathrm{cm}^{3}\right)\end{array}$ & $\begin{array}{r}12 \pm 0.82 \\
0.60 \pm 0.02\end{array}$ & $\begin{array}{l}16.3 \pm 4.5 \\
0.61 \pm 0.02\end{array}$ & $\begin{array}{l}13.7 \pm 1.24 \\
0.63 \pm 0.02\end{array}$ & $\begin{array}{c}16 \pm 4.5 \\
0.62 \pm 0.02\end{array}$ \\
\hline
\end{tabular}

注 : 平均値士標準誤差を示す. 

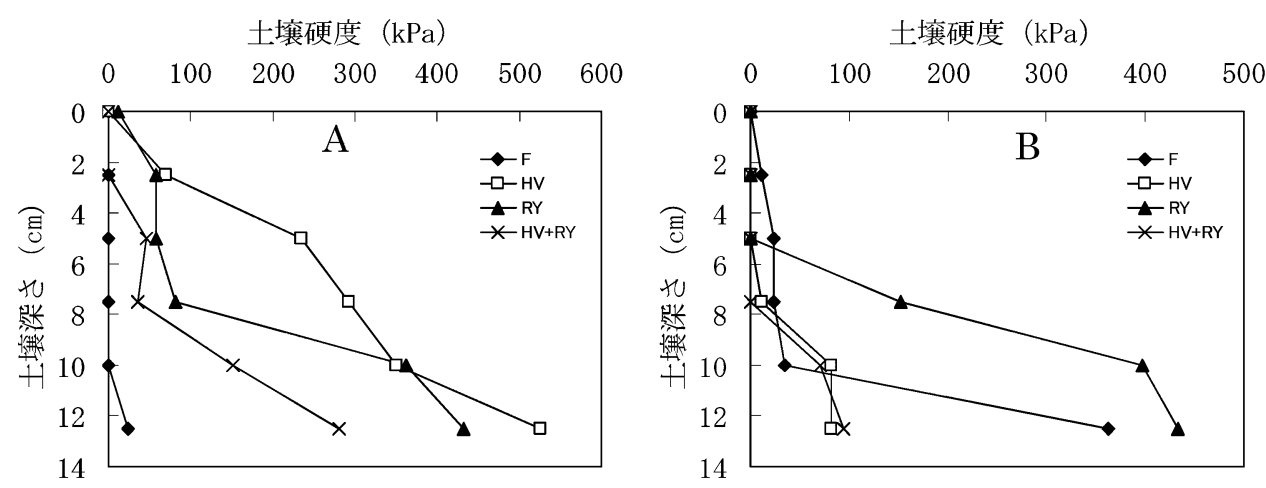

図 2 カバークロップ別での土壌硬度

注 : 1) 凡例の記号は F : 裸地, HV : ヘアリーベッチ, RY : ライムギ, HV+RY : ヘアリーベッチ+ ライムギの混播を示す.

2) $\mathrm{A}$ は 4 月 22 日, B は 5 月 10 日のデータを示す.

されているが（牟ら 2007），今回の実験ではカ バークロップ播種時にロータリ耕うんを行ってお り，裸地区で土壤が膨軟な状態で冬期間を推移し たのに対し, カバークロップ区では根系の発達な どにより土畩硬度がやや高い值を示したものと考 える. しかしながら, 不耕起播種機の播種溝深さ は 8 から $9 \mathrm{~cm}$ 前後であり,これらの土畩硬度の 差異は不耕起播種機の所要動力へは直接影響を及 ぼすことは少ないものと考えた。

2）カバークロップの種類と残渣処理がトラクタ の所要動力に与える影響

カバークロップの種類と残渣処理別のトラクタ PTO 軸トルクと回転数を図 3 に示した。これを みると, 回転数の変動範囲は 4 月 22 日では 282 $294 \mathrm{rpm}$ であり，5月 10 日では 278〜294 rpm で あった。またトラク夕の作業速度は $0.35 \mathrm{~m} / \mathrm{s}$ であ り, PTO 回転数と作業速度は処理間での差異が 少なかった。これに対し，PTO軸トルクをみる と, カバークロップの種類と残渣処理掞よび作業 時期により大きな差異が認められた。

PTO 軸トルクは，作業時期別にみると 5 月 10 日のほうが 4 月 22 日に比べて大きくなった。ま た, カバークロップの種類別にみると裸地区の卜 ルクが最あ小さく, 次いでヘアリーベッチであっ た. PTO軸トルクはライムギ区で最む大きくなっ たが，混播区では，ライムギ区に比べて PTO 軸 トルクはやや減少した。さらに，カバークロップ の残渣処理別にみると, PTO 軸トルクは残渣除 去区で最む小さくなり，次いでフレールモア区で

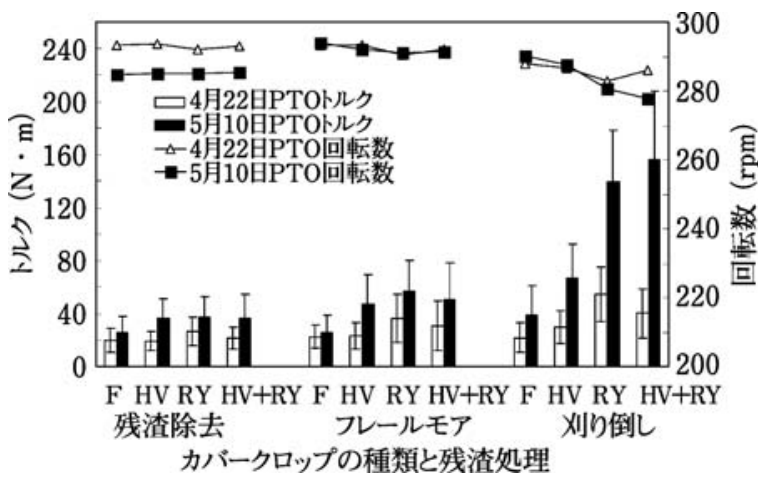

図 3 カバークロップ種類と残渣処理別での不 耕起播種機の PTO 軸トルクと回転数

注：1）横軸の記号は F : 裸地, HV : ヘアリーベッチ, RY : ライムギ, HV+RY : ヘアリーベッチ+ ライムギの混播を示す。

2）エラーバーは標準誤差を示す.

あり，刈り倒し区で最あ大きなトルクを要した， カバークロップの種類と残渣処理別での播種溝 深さを図 4 に示した。播種溝深さの変動範囲は 4 月 22 日では $8.3 \sim 11 \mathrm{~cm}$ であり, 5 月 10 日では 6.8 $\sim 11.3 \mathrm{~cm}$ であった. カバークロップの種類別に 見ると裸地とへアリーベッチでは播種溝深さは変 わらなかったが，ライムギ拈よびへアリーベッチ とライムギの混播ではやや浅くなった。 ライムギ や混播などカバークロップ残渣の量が多い区で は，播種溝深さがやや浅くなる傾向が認められ た.これに対し，カバークロップの残渣処理別で は播種传深さの差異がほとんど認められなかっ た。また，これらの区のダイズの播種深さはいず れも $2 \sim 3 \mathrm{~cm}$ の範囲内であり, 播種作業上の問題 


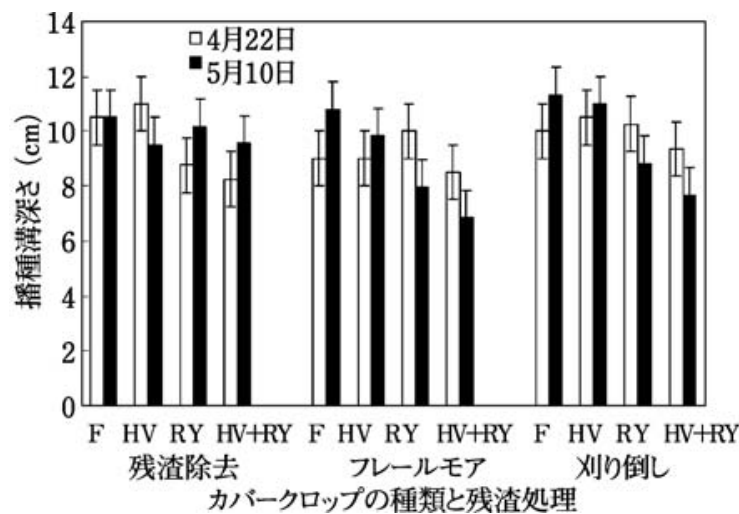

図 4 カバークロップ種類と残渣処理別で 不耕起播種機の播種溝深さ

注：1）横軸の記号は $\mathrm{F}:$ 裸地, HV :ヘアリーベッチ, $\mathrm{RY}:$ ライムギ，HV+RY：へアリーベッチ+ ライムギの混播を示す。

2）エラーバーは標準誤差を示す.

は認められなかった。

カバークロップの種類と残渣処理別での PTO 軸所要動力を図 5 に示した。これをみるとカバー クロップの種類と残渣処理別での所要動力は, PTO 軸トルクと同様の傾向を示した。作業時期 別にみると，5月 10 日の所要動力は 4 月 22 日よ り $51.1 \sim 171.7 \%$ 増加した。 また，カバークロップ の種類別にみると，裸地のトルクがもっとも小さ く, 次いでヘアリーベッチであった。これに対し, ライムギでは最も大きい所要動力を必要とし， ラ イムギとへアリーベッチの混播ではライムギに比 べて所要動力がやや減少した。また, 残渣処理別 にみると, 残渣除去区があっとも所要動力が小さ かったが，刈り倒し区ではフレールモア区に比べ て所要動力が $24.8 〜 197.0 \%$ 増加した.

これらのデータをみると, カバークロップ残渣 は, 不耕起播種機利用時のトラクタの PTO 軸卜 ルクを増加させ, 結果として所要動力を増加させ るなど大きな作業負荷となることが認められた。 特にライムギ区では所要動力が最む大きく, これ に対してヘアリーベッチ区では所要動力は裸地と ほぼ同等であった。このことから，カバークロッ プ残渣が不耕起播種機の所要動力に及ぼす影響を 考えると，カバークロップ残渣の物理的な性質に 大きく影響をうけるあのと考えられる。 ライムギ やへアリーベッチの茎の剪断応力をみると，へア リーベッチに比べてライムギで大きいことが認め られており (趙ら 未発表), このためカバークロッ

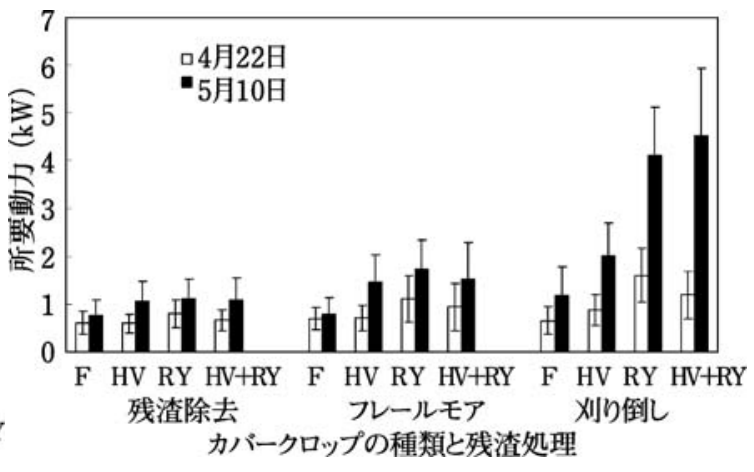

図 5 カバークロップ種類と残渣処理別での 不耕起播種機を利用した時の所要動力

注：1）横軸の記号は $\mathrm{F}:$ 裸地, HV : ヘアリーベッチ, $\mathrm{RY}:$ ライムギ, HV+RY : へアリーベッチ+ ライムギの混播を示す。

2）エラーバーは標準誤差を示す.

プ残渣の物理的な特性が不耕起播種機の所要動力 に影響を及ぼしているものと考えた。また作業時 期が遅くなるのに従ってカバークロップの乾物重 が増加したことで，4月 22 日に比べて 5 月 10 日 で所要動力が大きくなったものと考える.

3）カバークロップの残渣量が不耕起播種機の所 要動力に与える影響

カバークロップ残渣量あたりの所要動力を図 6 に示した。これをみると，5月 10 日に比べると， 4 月 22 日の不耕起播種機の所要動力が著しく減 少した。また，カバークロップの種類別にみると ライムギに比べてへアリーベッチやライムギとへ アリーベッチの混播区でカバークロップ残渣あた りの所要動力が減少した。また，残渣処理別にみ ると刈り倒し区に比べてフレールモア区では所要 動力が著しく小さい值を示した.

一般にカバークロップの残渣量が多くなるほ ど, 不耕起播種機を稼動するための所要動力は大 きくなるが（趙ら 2009）, 今回の試験において最 屯残渣量が大きかったライムギとへアリーベッチ の混播区において，カバークロップ残渣量あたり の所要動力がヘアリーベッチと同等の低い值を示 したことは興味深い. カバークロップの混播技術 は, 有機物確保や後作物への窒素供給などの点で 注目されているが（Sainju et al. 2006），混播技術 が不耕起播種機の作業性に及ぼす影響を検討した 事例は少ない，そのため，混播により不耕起播種 機の所要動力を減少させることができることは, 


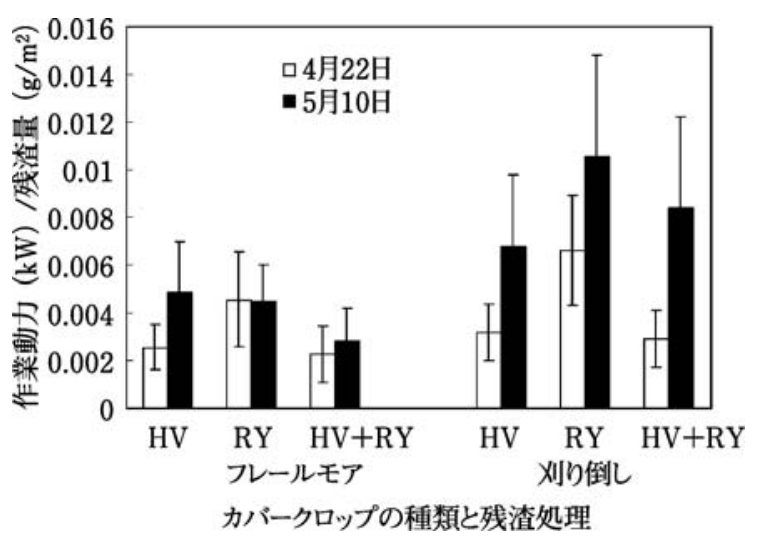

図 6 カバークロップ残渣量あたりの所要動力 注：1）横軸の記号は HV:ヘアリーベッチ, RY : ラ イムギ， HV+RY:ヘアリーベッチ+ライム ギの混播を示す。

2）エラーバーは標準誤差を示す.

日本における汎用型不耕起播種機とカバークロッ プの利用の組み合わせを考慮した農作業システム を構築していく上で重要な知見となるものと考え る.

以上の結果から，カバークロップの利用条件下 で不耕起播種機の作業性を確保するには, イネ科 とマメ科のカバークロップを混作し，十分な乾物 重を確保しかつフレールモアによる細断と組み合 わせることで，より駆動力の小さなトラクタを中 心とした機械化体系が可能であることが認められ た。

今回の報告では, カバークロップの種類と残渣 処理が不耕起播種機の作業動力に及ぼす影響につ いて検討を進めてきたが，不耕起播種機の作業性 を総合評価するには作物残渣が溝切りローターに 絡まることや，作物残渣が播種溝形成に悪影響を 及ぼすこと, 種子の播種深さおよび播種量, 播種 間隔などについても詳しい調査が必要である。こ れらの点については今後検討を進める予定であ る.

また，不耕起播種機は土壤硬度の大きい圃場で の播種作業に対応するため作業機の質量の増加な どの問題もあり, 不耕起播種作業におけるトラク 夕動力を削減するためには PTO 軸動力以外にも 3 点リンクの揚力などの観点からの検討も重要で ある。不耕起栽培は農業生産に要する投入エネル ギを慣行の農業システムに対して削減することが できるが，より少ない駆動力で不耕起播種可能な
作業システムを開発するには，作業動力のみなら ず作業機械構造の観点から検討する必要がある.

\section{4. 摘要}

本研究では, カバークロップの種類および残渣 処理による不耕起播種機利用時のトラクタの所要 動力の差異を検討した得られた結果は以下のとお りである.

1）カバークロップの種類別にみると，ライムギ 区に比べてへアリーベッチ区や混播区で不耕起播 種機利用時の所要動力が減少した.

2）カバークロップの残渣処理により, 不耕起播 種機利用時の所要動力に差異が認められた. 草刈 り機による刈り倒しに比べてフレールモアでのカ バークロップ残渣の細断により, 所要動力は減少 した.

3) カバークロップ残渣量が多くなると, 不耕起 播種機利用時の所要動力が著しく大きくなった. カバークロップ残渣あたりの所要動力をみると, ライムギ区が最む大きくなったが，へアリーベッ チ区と混播区では, 残渣量あたりの所要動力は減 少した。

4）カバークロップの利用条件下で不耕起播種 機の作業性を確保するには，イネ科とマメ科の力 バークロップを混播し，十分な乾物重を確保しか つフレールモアによる細断と組み合わせることが 有効であることが認められた

$$
\text { キーワード }
$$

カバークロップ, 不耕起播種機, 所要動力, ライ ムギ，ヘアリーベッチ

\section{引用文献}

Abdul-Baki, A.A., J.R. Teasdale and R.F. Korcak (1997) : Nitrogen requirements of fresh-market tomatoes on hairy vetch and black polyethylene mulch, HortScience 32 (2) ; 217221.

荒木 肇・石本光明・松尾信由・伊藤道秋 (2006)： カバークロップ残渣で被覆した不耕起圃場の 土壤硬度と機械播種したダイズの初期成長, 農作業研究 44（4）；180-184.

Araki, H., M. Ito (1998) : Soil properties and vegetable production with organic mulch and no-tillage system. Japanese Journal of Farm 
Work Research 34 (1) ; 29-38.

趙 艶忠・趙 鉄軍・小松㠃将一（2009）：力 バークロップ利用条件下での不耕起播種機の 作業性, 農作業研究第 44（別 1)；117-118.

Edelhar, S.A., W.W. Frye and R.L. Blevins (1984) : Nitrogen from legume cover crop for notillage corn, Agron. J. 76 ; 51-55.

Ferreras, L.A., J.L. Costa, F.O. Garcia, and C. Pecprari (2000) : Effect of no-tillage on some soil physical properties of a structural degraded Petrocalcic Paleudoll of the southern "Pampa" of Argentina. Soil Tillage Res. $54 ; 31-39$.

Gong,L., H. Gao and J. Jiang (2008) : Experimental study on power dissipation of corn rootstalk treatment device of no-tillage planter, Transactions of the CSAE 24 (7) ; 124-127.

古 松. 小松嵉将一・森泉昭治・高橋雅之・池田 正則 (2002) : カバークロップの種類と刚取 りの有無がロータリ耕うん性能に及ぼす影 響, 農作業研究 37 (1)；13-23.

後藤隆志 (1995): 有機物の施用方法と機械利用, 土壤施肥編, 農業技術大系 (5), 農山魚村文化 協会, 東京, $164 ; 10-13$.

岩手県農業研究センター（2003）：ダイズ不耕起 播種機の作業特性, 岩手県農業研究センター 研究レポートNo 209, 岩手県.

金谷 豊・梅田直円・長坂善偵・国立卓生（2005）： LCA 手法による不耕起播技術の環境負荷軽 減効果の試算, 農作業研究第 40 (別 1)；1-2.

Komatsuzaki, M., S. Moriizumi and O. Endo (1998) : Subterranean Clover Reseeding and Seed Survival in Upland Fields, Japanese Journal of Farm Work Research 33 (2) ; 6371.

Liu, F. and B. Chen (2008) : The influence about straw mulching quantity to the no-tillage planter performance,Science and Technology of Tianjin Agriculture and Forestry, $10(5) ; 32-33$.

McVay, K.A., D.E. Radcliffe and W.L. Hargrove. (1989) : Winter legume effects on soil properties and nitrogen fertilizer requirements, Soil Sci. Soc. Am. J. 53 ; 1856-1862.

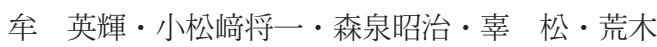

肇・平田聡之 (2007)：オカボ栽培でのカバー クロップの利用と耕うん方法が土䁃物理性に 及ぼす影響, 農作業研究 42 (1) ; 11-20.

Myers, J. and M.G. Wagger (1991) : Reseeding potential of crimson clover as a cover crop for no-tillage corn, Agron. J. 83 (6) ; 985991.

西崎邦夫 (1995): 緑肥の機械化栽培, トラクタ処 理技術, 緑肥の利用と機械化栽培, 農業機械 学会北海道支部, pp. 30-34.

Oyer, L.J. and J.T.T. touchton (1990) : Utilizing legume cropping system to reduce nitrogen fertilizer requirements for conservation-tilled corn. Agron. J. 82 ; 1123-1127.

Peet, M. (1996) : Sustainable practices for vegetable production in the south, Focus publish, R. Pullins Company, MA, U.S.A, pp. 129.

Ranells, N.N. and M.G. Wagger (1992) : Crimson clover management to enhance reseeding and no-till corn grain production, Agron. J. 85 (1) ; 62-67.

Sarrantonio, M. (1989) : Selecting the best cover crops for your farm, Managing cover crops profitably, Sustainable Agriculture Network, MD, U.S.A, pp. 12-15.

Sainju, U.M. and B.P. Singh (1997) : Winter cover crops for sustainable agricultural systems : influence on soil properties, water quality, and crop yields. HortScience 32 ; 21-28.

Sainju, U.M., Whitedhead, W.F., Singh, B.P. and Wang, W. (2006) : Tillage, cover crops, and nitrogen fertilization effects on soil nitrogen and cotton and sorghum yields, Europ. J. Agronomy 25 ; 372-382.

Teasdale, J.R. (1993) : Reduced-herbicide weed management systems for no-tillage corn in a hairy vetch cover crop, Weed Technol. $9 ; 113-118$.

Touchton, J.T., W.A. Garder, W.L. Hargrove and R.R. Duncan (1982) : Reseeding Crimson clover as a $\mathrm{N}$ source for no-tillage grain sorghum production. Agron. J. 74 ; 283-287.

Triplett Jr., G.B., S.M. Dabney and J.H. Siefker (1996) : Tillage Systems for Cotton on Silty 
Upland Soils. Agon. J. 88 ; 507-512.

Wagger, M.G. (1989) : Cover crop management and nitrogen rate in relation to growth and yields on no-tillage corn. Agron. J. 81; 533-538.

Wood, C.W., J.H. Edwards and C.G. Cummins (1991) : Tillage and rotation effects on soil organic matter. 1991 Southern Conservation Tillage Conference, Arkansas, pp.103106.

安江多輔 (1993)：日本に捛けるレンゲの栽培管 理および利用, レンゲ全書, 農文協, 東京, pp. 80-98.

\section{Summary}

No-tillage with cover crop has great potential to improve soil quality, however, it is still not clear what no-tillage seeding technique should be used under cover crop residue mulch in upland crop production. In this research, to identify the optimum no-tillage seeding management, no-tillage seeder performance and power requirement were measured in relation to different cover crop residue management.
The tractor power required for the no-tillage seeder was higher with rye cover crop than hairy vetch and a mixture of rye and hairy vetch. Cover crop residue also showed a significant difference in the power required by the no-tillage seeder. Mowing the cover crop significantly reduced the power requirement compared with bush cutting. Termination of cover crop growth was another factor that significantly affected the power required. Late April growth termination of cover crop showed a lower power requirement than early May growth termination. As the amount of cover crop residue increased, the power requirement also increased, although the rye and hairy vetch mixture showed relatively lower power requirement. These results suggest that rye and hairy vetch mixture and mowing treatment are appropriate for using a no-tillage seeder under cover crop residue mulch.

\section{Key Words}

Cover crops, No-tillage seeder, Power requirement, Rye, Hairy vetch 